\title{
Sasolahan Legong Dedari \\ di Pura Luhur Catur Kanda Pat Sari Pangideran Dewata Nawa Sanggha (Kajian Teo- Estetik)
}

\author{
I Nyoman Linggih ${ }^{1}$, I Ketut Muka² \\ ${ }^{1}$ Program Pascasarjana Institut Hindu Dharna Negeri Denpasar \\ ${ }^{2}$ Fakultas Seni Rupa dan Desain, Institut Seni Indonesia Denpasar \\ manlinggih@gmail.com
}

\begin{abstract}
Selama kurang lebih 60 tahun silam Sasolahan Legong Dedari tidak ditarikan, belakangan ini mulai Sasolahan Legong Dedari ditarikan kembali mengingat terjadinya fenomena aneh yaitu; terjadinya secara berturut-turut penduduk meninggal hingga delapan orang (grubug), uang sesari di balai banjar hilang misterius, warga banjar yang tidak harmonis dan terjadinya trend (kerauhan) yang mengisyaratkan beliau Ida Ratu Ayu Mas Maketel (Rangda) berkeinginan untuk tedun masolah kembali (napak pertiwi) diiringi Sasolahan Legong Dedari. Sasolahan Legong Dedari yang tergolong tari Sakral ini hanya ditarikan ketika Upacara piodalan di Balai Banjar Pondok, dan Upacara Piodalan di Pura Luhur Kanda Pat Sari Pangideran Dewata Nawa Sanggha. Penari Sasolahan Legong Dedari wajib hukumnya untuk mengikuti upacara penyucian sebelum menari.Ditarikan kembali Sasolahan Legong Dedari serta Ida Ratu Ayu Mas Maketel (Rangda) Napak Pertiwi tiada lain untuk menetralisir kembali, agar hal-hal aneh tidak terjadi lagi di wilayah Desa Banjar Pondok. Demikian juga masyarakat sangat meyakini dengan ditarikan Sasolahan Legong Dedari serta Ida Ratu Ayu Mas Maketel, merupakan simbol turunnya Ida Sanghyang Widhi Wasa (manifestasinya) diiringi para Widyadara- Widyadari, dapat menyucikan kembali wilayah serta isinya, sehingga masyarakat dapat hidup rukun, damai, tentram sejahtra serta bersenang hati untuk senantiasa meyakini Pura Luhur Kanda Pat Sari Pangideran Dewata Nawa Sanggha dilestarikan sebagai tempat suci pemujaan Beliau.
\end{abstract}

Kata kunci : sasolahan legong dedari dan teo-estetik

\section{Legong Dedari Dance In Luhur Kanda Pat Sari Pangideran Dewata Nawa Sanggha Tample (Teo-Aesthetic Study).}

Amost 60 years the Legong Dedari dance has never been performed at Desa Banjar Pondok.However, the deaths of some of the villagers recently, the lost of the donated money from the village compound, personal problems between some villagers, the sudden in- transce people, have been all interpreted to sign that Ida Ratu Ayu Mas Maketel or the village Rangda, was calling for a dancing ritual with the Legong dance. The sacred dance is traditionally performed during the festival of Pura Luhur Kanda Pat Sari Pangideran Dewata Nawa Sanggha and performed by the dancers who have to be purified ritually beforehand. Recently the sacred dance was performed only for neutralizing and returning the harmony of the village as the villagers believe that it represented the coming and presence of the God and goddeses at the village.

Keywords, legong dedari dance and theo-aesthetics

Proses Review : 2 - 28 Januari 2021, Dinyatakan Lolos: 16 Februari 2021 


\section{PENDAHULUAN}

Bali dikenal dengan berbagai julukan seperti ; Bali sebagai pulau Dewata, Bali sebagai pulau surga, Bali sebagai pulau seribu pura, bahkan Suhardana (2015 : 3), menyebutkan sebanyak 12.000 atau lebih jumlah pura yang ada di Bali. Penduduk Bali yang nota bena beragama Hindu, menurut Duija (2019 : 1) kebertahanan dan pertumbuhan serta perkembangan seni di Bali secara tidak langsung disebabkan oleh kuatnya system keagamaan Hindu yang dianut oleh orang Bali. Keterkaitan seni dan agama tersebut adalah saling mengisi dan saling menguatkan. Gusti Bagus Sugriwa, (1952:22) menegaskan, kapan Bali tidak lagi beragama Hindu, jangan harap Bali akan dikunjungi pariwisata Dunia, bahkan Bali akan sirna di mata Dunia (Parama Satya). Mantra (1991:5-18), menyatakan hubungan antara agama Hindu dengan seni tak dapat dipisahkan. Bahkan tanpa kehadiran seni, upacara agama dianggap belum sempurna. Dalam hal ini hubungan agama Hindu dengan seni sangat erat sehingga dapat menumbuhkan rasa seni yang sangat mendalam pada masyarakat di berbagai bidang, seperti: bidang seni pahat, seni gamelan, seni lukis, seni tari, seni hias, seni patung, seni krya dan lain-lain. Fenomena ini digaris bawahi oleh Albert Eistein (dalam Wiana, 2014:3) memberi pandangan bahwa:1. Agama mengarahkan hidup, 2. Ilmu memudahkan hidup, 3. Seni menghaluskan hidup. Dari pandangan di atas, yaitu, 1. Agama mengarahkna hidup, bagi masyarakat Bali dalam berprilaku tidak bisa lepas dari ajaran Agama Hindu, karena ajaran agama Hindu ibaratkan sebagai sinar yang dapat memberikan petunjuk atau penerangan untuk menuju jalan hidup yang baik dan benar yang dikenal dengan istilah Satyam yaitu kebenaran. 2. Ilmu memudahkan hidup, bagi masyarakat Bali memaknai bahwa selama hidup orang Bali tidak henti-hentinya untuk belajar menuntut ilmu pengetahuan, karena ilmu pengetahuan bagi masyarakat Bali tidak akan habis-habisnya untuk dipelajari dan dengan modal ilmu pengetahuan akan dapat memberikan kehidupan yang lebih layak, dengan semboyan orang Barat yaitu long life ejukations. Dan yang ke 3. Seni menghaluskan hidup, diimplementasikan oleh orang Bali untuk berkreativitas dalam kehidupan berkesenian sebagai media untuk menghubungkan dirinya dengan sumbernya yaitu Ida Sanghyang Wdhi Wasa tiada lain Siwanataraja yang diyakini sebagai Dewa Kesenian yang dapat memberikan keindahan, menuju kedamaian yang abadi.

Salah satu seni tari sebagai media tersebut adalah, sesolahan legong dedari di Pura Luhur Kanda Pat Sari Pengideran Dewata Nawa Sanggha Banjar Pondok Peguyangan Kaja Denpasar Utara Kodya Denpasar. Legong dedari ini hanya ditarikan ketika upacara piodalan. Menurut Jero Mangku Niang (wawancara, 2 Agustus 2019) bahwa, sejak enam puluh tahun silam legong tidak menari, saat ini para penari yang dulu sudah tiada, sehingga Ida Bhatara tidak ada lagi yang menarikan, gelungan pajenengan yang sacral disimpan di balai banjar. Belakangan ini ada penomena yang aneh, dimana masyarakat Banjar Pondok mengalami grubug yaitu kematian yang berturut-turut hingga delapan orang yang menjadi korban. Uang dana punia di balai banjar juga hilang dengan misterius, terjadinya salah satu warga masyarakat kerauhan, dia mengatakan bahwa Ida Bhatara sasuhunan agar kembali napak pertiwi diiringi Tarian Legong Dedari. Masyarakat bermusyawarah dan menyepakati untuk menarikan kembali sasuhunan dengan iringan legong dedari. Jadi Legong Dedari masolah karena kehendak Ida Bhatara Sasuhunan yang melinggih di Pura Luhur Catur Kanda Pat Sari Pangiderin Dewata Nawa Sangga. Tanggal 25 September 2018, Sesolahan Legong Dedari ditarikan pertama kali sejak 60 tahun silam, sebagai awal Ida Betara Napak Pertiwi (nuasen). Dalam pementasan ini dirasakan masyarakat belum sempurna, mereka berharap agar Sesolahan Legong Dedari lebih baik sempurna, maka dilakukan Rekontruksi oleh ISI Denpasar. Ketika Upacara Piodalan di Pura Kanda Pat Sari, (hari Selasa, 23 April 2019) pementasan kedua sebagai hasil sentuhan (rekontruksi) ISI Denpasar yang dirasakan masyarakat sasoloahan yang paling pas dan sempurna. Sasolahan legong dedari religious ini, menunjukan banyak keajaiban dan keanehan dari tarian legong pada umumnya.

Sasolahan legong dedari ditarikan oleh dua belas orang wanita remaja, dengan pakaian khusus dan khas, mengikuti warna pengider - ider Buana. Menurut Jero Serati (wawancara, 5 Mei 2019) ketika legong masolah, dipersembahkan segan 33 tanding dan sambleh. Ida Bhatara sasuhunan kapundut ngider buana ping tiga, keliling kalangan 3 kali kearah kanan. Para penari Legong Dedari mejaya-jaya natab banten pabyakalan, sembahyang dan nunas tirta, dituntun oleh 2 Orang mangku. Sedangkan tarian pelegongan hanya sembahyang dan nunas tirta. Tari Legong Dedari ini, diiringi dengan tabuh gamelan pelegongan yang khas legong dedari Banjar Pondok. Penari legong dedari ketika masolah pada tahapan pertama ; menari enam orang, masing-masing dua orang memakai pakaian putih dengan posisi di arah Timur, pakaian merah di arah Selatan, pakaian kuning di arah Barat, pakaian hitam di arah Utara. Posisi ini menjadi perbedaan prinsip dengan tarian legong pada umumnya, Pada tahapan kedua menari lagi empat orang penari juga masing-masing seorang warna putih, merah, kuning dan hitam mengikuti posisi tarian sebelumnya. Pada tahapan ke tiga, dua penari yang mundut gelungan sacral pakian hitam dan putih keluar menari. Sedangkan penari rangda, pemundut keris, kober bergambarkan Anoman, selesai mengikuti upacara penyambleh, atau katuran labaan, keluar pada tahapan keempat, pada tahapan inilah dua penari yang mundut gelungan sakral menjemput (mendak) Ida Sasuhunan (Ida Ratu Ayu Mas Maketel yang mapalawatan Rangda), menari dan menurut Pujawan (wawancara,21 Sepetmber 2019) membentuk komposisi Bungan Tunjung, Rangda yang ada di tengah-tengah sebagai Siwa Pasupati, menari bergerak memutar ke arah kiri, legong dedari 
memutar kekanan, sebanyak tiga kali. Selesai gerakan memutar dilakukan suasana berubah dari yang hening, tenang menjadi misterius, religious, menakutkan semua menari dalam keadaan tidak sadar. Tarian ini tidak dialami oleh penari pelegongan pada umumnya. Rangda menari menunjukan karakter Dewa Siwa, ucapan serta gerakannya sangat aneh dan ajaib menuju jeroan Pura Luhur Kanda Pat Sari. Menjelang pagi sebagai akhir tarian legong Dedari ini suasana berubah dimana para penari naik dari kolam menuju pelinggih pangider Buana masing-masing. Pada masing-masing di hadapan Pelinggih tersebut para penari yang tidak sadarkan diri ini di persembahkan dan diprosesi dengan upacara ngeluhur atau mesineb diperciki tirta maka para penaripun mulai sadar.

Berkaitan dengan uraian di atas muncul permasalahan yakni bagaimanakah prosesi yang wajib dilakukan ?, apakah fungsi sesolahan legong dedari ? dan bagaimanakah makna symbol Estetika Hindu tercermin pada Sesolahan Legong Dedari dalam kaitannya dengan upacara Piodalan di Pura Luhur Kanda Pat Sari Pengideran Dewata Nawa Sanggha di Banjar Pondok?.

\section{METODE PENELITIAN}

Penelitian seni tari ini merupakan jenis penelitian kualitatif. Penelitian kualitatif bertitik tolak dari paradigma fenomenologis. Obyektivitas penelitian kualitatif dibangun atas rumusan tentang situasi tertentu sebagaimana yang dihayati oleh individu atau kelompok social tertentu, dan relevan dengan tujuan penelitian (Alsa,2004:31). Ciri-ciri terpenting metode kualitatif, adalah (1) memberikan perhatian utama pada makna dan pesan, sesuai dengan hakikat obyek, yaitu sebagai studi kultural; (2) lebih mengutamakan proses dibandingkan dengan hasil penelitian sehingga makna selalu berubah; (3) tidak ada jarak antara subyek peneliti dengan obyek penelitian, subyek peneliti sebagai intrument utama, sehingga terjadi interaksi langsung di antaranya; (4) desain dan kerangka penelitian bersifat sementara sebab penelitian bersifat terbuka; (5) penelitian bersifat alamiah, terjadi dalam kontek social budayanya masing-masing (Ratna, 2004:47-48). Terkait dengan jenis penelitian ini, maka data penelitian ini didapat dengan dokumentasi teknik, rekam, catat dan foto. Data yang didapat dianalisis dengan teori; Interaksionisme Simbolik, Fungsional Struktural, dan Estetika.

\section{ANALISIS DAN INTERPRETASI DATA}

\section{Sejarah Pura Luhur Catur Kanda Pat Sari Pengideran Dewata Nawa Sanggha}

Pura yang berlokasi di Banjar Pondok Peguyangan Kaja Kodya Denpasar ini, menurut Suhardana (2015:50) ditinjau dari konstelasi pelinggihnya, pura ini sangat unik. Belum pernah ditemukan Pura yang secara strukturalnya seperti pura ini. Walau unik namun tidak berarti aneh, karena pola yang dipakai sangat baku, yaitu Pangiderider Dewata Nawa Sangga yang sudah kita kenal. Pura ini disungsung oleh keluarga Jero Pemangku Pura sejak sepuluh keturunan dari nenek moyangnya. Menurut perkiraan, mungkin Pura ini sudah ada sejak abad ke 17 atau 18. Pura ini terletak di tepi, di Jalan Antasura (Jalan Nangka Utara) menuju instalasi penjernihan air PDAM di Belusung, Denpasar Utara. Aura kesakralan Pura yang kental, cobaan hidup yang sedang dialami oleh keluarga Jero Mangku Istri Desak Nyoman Rai dan Jero Mangku Dewa Made Agung Suci sekeluarga sangatlah memilukan. Telaga yang menjadi unsur yang sangat penting di Pura ini telah mengalami perbaikan dengan air yang yang sangat jernih dilengkapi dengan bunga tunjung berwarna-warni sesuai dengan warna pengider buana. Berkah Ida masih terus mengalir bagi mereka yang mampu menunjukan ketulusan menghaturkan bhakti kehadapan beliau. Idealnya haturan banten terdiri dari 9 perangkat untuk Sembilan pengider-ider. Dilihat dari keadaan seluruh pelinggihnya yang ada, mestinya adalah Pura Kahyangan Jagat. Pelinggih memuja Dewata yang menjaga 9 penjuru bhuana.

Sedangkan berdasarkan Mitologi dan Sejarah oleh, Tim (2016 : 11-18) diuraikan, berbeda dengan beberapa pura lainnya yang tergolong kahyangan jagat, yang selalu dikaitkan dengan turunnya putra-putra Sang Hyan Pasupati yang kemudian berstana di beberapa pura yang tergolong Sad Kahyangan, dan pura yang dikaitkan dengan kedatangan para rohaniawan (Dangacarya) yang kemudian berstatus sebagai Dangkahyangan. Mitologi dan sejarah Pura Luhur Catur Kanda Pat Sari Pengideran Dewata Nawa Sanga ini masih sulit untuk direkonstruksi, karena data yang terkait sangat minim. Menurut Jero Mangku Niang (wawancara 1 September 2019) pada awalnya pura ini dibangun oleh leluhurnya, Dewi Ibu, pada bancangah Dewa Manggis Kuning yang disimpan disana menyebutkan Dewa Alit dari Peraupan beristri dengan Jero Manoraga dari Kadua, kemudian setelah madwijati bergelar Dewi Ibu, lebih lanjut secara mitologis Jero Mangku Gde Istri, menjelaskan bahwa, Jero Manoraga yang bergelar Dewi Ibu ini konon memiliki kelebihan dari manusia biasa, memiliki kesaktian, yaitu ketika hamil jika beliau merasa letih membawa kandunganya ia dapat menitipkan anak dalam kandunganya tersebut pada bunga teratai, sehingga di areal Pura Luhur Catur Kanda Pat Sari Pangideran Dewata Nawa Sanga, selalu ditanami bunga teratai. Setelah putranya lahir keanehan kembali terlihat putranya yang lahir tidak memiliki pusar, keduanya sangat sakti, baik Jero Manoraga yang bergelar Dewi Ibu dan juga anak yang dilahirkanya, sehingga disegani oleh orangorang dan mampu menyembuhkan orang, Beliau Jero Manoraga yang bergelar Dewi Ibu tersebut juga memiliki jnana yang tinggi, beliau konon bisa pulang pergi ke sorga dan kembali kedunia, apa yang beliau lihat di sorga lalu dibuat di dunia, sehingga dibuatlah Pura Luhur Catur Kanda Pat Sari Pangideran Dewata Nawa Sanga. Pada saat 
membuat pura tersebut konon tidak dibuat oleh manusia biasa, melainkan ada para pengayah atau orang-orang yang datang membantu namun entah dari mana asalnya, serempak datang para pengayah di timur, selatan, barat, utara dan setiap sudut, bersorak sorai, lalu secara tak kasat mata Pura Luhur Catur Kanda Pat Sari Pangideran Dewata Nawa Sanga tiba-tiba telah selesai dibangun. Setelah wafat Dewi Ibu ini konon meminta untuk dikubur di jaba pura kahyangan, dan setelah beberapa hari dibongkar kembali, akan tetapi jasad beliau sudah tidak ada hanya tersisa berupa kwangen saja, sehingga diyakini beliau Jero Manoraga yang bergelar Dewi Ibu moksa. Bila ditinjau dari nama pura itu yakni Pura Luhur Catur Kanaa Pat Sari Pangideran Dewata Nawa Sanga, maka secara etimologis adalah; "luhur, 'tinggi'; catur berarti 'empat'; kanda berarti 'ajaran. 'cerita; 'tingkahlaku/perilaku, "kesaktian, kemanjuran'; pat berartt empat' dan sari bararti 'inti'; 'utama. Pangideran berasal dari kata ider yang mendapat awalan pa dan akhiran an. Kata ider berarti 'keliling, imbuhan pa- dan akhiran -an, mempunyai arti 'tempat, 'kumpulan, keseluruhan. Dewata Nawa Sanga (Sanggha) berarti kelompok Sembilan Dewa yang menduduki penjuru mata angin. Dengan demikian Catur Kànda Pat Sari berarti 'empat ajaran utama tentang atau untuk mencapai kesaktian atau kemanjuran' (Yendra, 2007:15), yang merupakan kekuatan atau pancaran sinar suci dari kelompok sembilan Dewa (Dewata Nawa Sanggha) yang menduduki sembilan penjuru mata angin. Sesungguhnya kanda pat merupakan salah satu aliran spiritual dan kebathinan yang berkembang di Bali yang di dalamnya menguraikan berbagai teori tentang kehidupan manusia dari awal hingga akhir, serta berbagai kekuatan yang diberkahi Dewa untuk melindungi manusia dari berbagai macam gangguan (Nantra, 2011:2-3). Dalam Kanda Pat Sari disebutkan, ada banyak intisari/ kekuatan/daya dalam tubuh manusia yang harus mendapat perhatian yakni ada intisari yang perlu dihidupkan, dikembangkan karena sangat bermanfaat bagi kehidupan manusia; ada kekuatan yang perlu dikendalikan karena kekuatan tersebut dapat merusak atau mendukung kehidupan manusia; ada intisari yang patut dilindungi karena dapat menentukan hidup-matinya manusia. Intisari/kekuatan/daya dalam tubuh manusia itulah yang disebut sarining merta/mreta. Cara menghidupkan, mengembangkan, mengendalikan dan melindungi intisari/kekuatan/daya (sarining merta/ mreta) tersebut yakni meditasi, dengan mengikuti tuntunan meditasi yang diturunkan oleh Bhatara Siwa dan merupakan meditasi khusus yang disebut 'meditasi sarining merta' agar dapat membuka, membangkitkan dan menghidupkan Tirta Amerta (panca tirtha) yang ada dalam diri manusia. Dalam prakteknya Tirta Amerta itu diposisikan di empat penjuru mata angin dan di tengah-tengah uttama mandala pura sebagai pusatnya dan dilindungi oleh Panca Dewata. Tirta Kamandalu terletak di Utara pada tetamanan Bhatara Wisnu, Tirta Sanjiwani berada di Timur pada tetamanan Hyang Iswara, Tirta Pawitra terletak di Selatan pada tetamanan Hyang
Brahma, Tirta Kundalini terletak di Barat pada tetamanan Hyang Mahadewa dan Tirta Mahamerta Kesuma tertetak di tengah pada palinggih Hyang Siwa. Menurut sejarahnya Kanda Pat dan tuntunan meditasinya turunnya di Gunung Batukaru pada tahun 463 Saka/ 541 Masehi di pertapaan yang disebut pertapaan Candra Parwata oleh Bhatara Siwa Selain tuntunan meditasi Sarining Merta, juga diturunkan tuntunan meditasi Sarining Ucap dan tuntunan meditasi Sarining Raksa. Keempat penuntun ajaran meditasi inilah yang disebut Kanda Pat Sari (Nantra, 2011:9-15). Seperti nama yang tersurat pada papan nama pura, pura itu juga sebagai tempat pemujaan sembilan dewa yang merupakan putra-putra Sang Hyang Pasupati yang berstana di Gunung Mahameru. Kesembilan dewa tersebut dititahkan oleh ayahandaNya untuk turun ke Bali (Bangsul), berstana di puncak-puncak gunung yang ada di sekeliling pulau Bali dan di dataran yang berada di tengah-tengah pulau, agar pulau Bali menjadi stabil atau kokoh.

\section{Struktur Palinggih-Palinggih Di Pura Luhur Catur Kanda Pat Sari Pengideran Dewata Nawa Sanggha.}

Adapun struktur Palinggih yang terdapat di Pura ini sebagai berikut:

\section{Palinggih Bhatara Siwa}

Palinggih yang paling besar dan terletak tepat di tengahtengah areal/Jeroan Pura, dengan bentuk bangunan segi empat sama sisi, berbentuk Pangaruman bermuka empat dengan dinding batu bata merah, dengan 4 tiang penyangga bangunan dan menghadap ke empat penjuru arah mata angin,dengan masing-masing arah angin terdapat 7 tangga.

\section{Palinggih Bhatara/Hyang Iswara}

Palinggih Bhatara Iswara berbentuk Padma Capah, pada Palinggih ini terdapat 5 buah Padma kecil, serta agak ke depan terdapat Arca/Pratima Bhatara Iswara. Pelinggih Bhatara Isara yang terletak di posisi Timur areal Pura yaitu di sebelah Timur Palinggih Bhatara Siwa, menghadap ke arah Barat. Warna kostumnya adalah warna Putih.

\section{Palinggih Hyang Maheswara}

Palinggih ini sesuai Pangideran Buana terletak pada posisi antara Palinggih Bhatara Iswara di Timur, dengan Palinggih Hyang Brahma di Selatan. Palinggih Hyang Maheswara di arah Tenggara (Kelod Kangin) berbentuk Dugul Tumpang 8, dengan warna kostum Biru Muda.

\section{Palinggih Bhatara/Hayng Brahma}

Palinggih ini berbentuk Padma Capah, pada Palinggih ini terdapat 9 buah Padma Kecil di depan Padma kecil terdapat arca/pratima Bhatara Brahma, Pelinggih ini terletak di posisi Selatan areal Pura yaitu di sebelah Selatan Palinggih Bhatara Siwa, menghadap kearah Utara. Dengan kostum Warna merah.

\section{Pelinggih Bhatara/Hyang Rudra}


Palinggih ini sesuai Pangideran Buana terletak pada posisi antara Palinggih Bhatara Brahma di Selatan, dengan Palinggih Hyang Mahadewa di Barat. Palinggih Hyang Rudra di arah Barat Daya (Kelod Kauh) berbentuk Dugul Tumpang 3, dengan warna kostum warna Jingga.

\section{Palinggih Bhatara/Hayng Mahadewa}

Palinggih Bhatara/Hyang Mahadewa berbentuk Padma Capah, pada Palinggih ini terdapat 7 buah Padma Kecil, di depan Padma kecil terdapat arca/Pratima Bhatara Mahadewa, Pelinggih ini terletak di posisi Barat areal Pura yaitu di sebelah Barat Palinggih Bhatara Siwa, menghadap kearah Timur. Dengan kostum berwarna Kuning.

\section{Pelinggih Bhatara Sangkara}

Terletak di Areal Tengah-Tengah antara Barat dan Utara yaitu Barat Laut (Kaja Kauh) terdapat Pelinggih Bhatara Sangkara, bangunannya berupa Dugul Tumpang 3, menghadap ke Tenggara, warna kostum adalah warna Hijau tua.

\section{Palinggih Bhatara/Hayng Wisnu}

Palinggih ini berbentuk Padma Capah, pada Palinggih ini terdapat 4 buah Padma Kecil, di depan Padma kecil terdapat arca/Pratima Bhatara Wisnu, Pelinggih ini terletak di posisi Utara areal Pura yaitu di sebelah Utara Palinggih Bhatara Siwa, menghadap kearah Selatan, dengan kostum warna hitam.

\section{Pelinggih Bhatara/Hyang Sambu}

Terletak di Areal Tengah-Tengah antara Utara dan Timur, yaitu Timur Laut (Kaja Kangin) terdapat Pelinggih Bhatara/Hyang Sambu, bangunannya berupa Dugul Tumpang 6 berwarna Biru Muda, menghadap ke Tenggara.

\section{Prosesi Sasolahan Legong Dedari Di Pura Luhur Catur Kanda Pat Sari Pengideran Dewata Nawa Sanggha.}

Ketika Upacara Piodalan Tumpek Wayang di Bale Banja, menurut Yuniati ( wawancara, 21 September 2019) baik penari maupun Ida Betara wajib mengikuti prosesi penyucian di pagi hari di Pura Luhur Catur Kanda Pat Sari Pangideran Dewata Nawa Sanggha. Hal ini dibenarkan oleh Jero Mangku Ruda (wawancara,7 September 2019), diperkuat oleh Jero Mangku Sudiarta (wawancara, 7 September 2019) menegaskan bahwa, Ida Sasuhunan sebelum napak pertiwi, dipersembahkan banten yaitu : Pejati, segan, sambleh Ayam Selem, dilanjutkan beliau bergerak memutar keliling kearah kiri tiga kali (napak pertiwi ngider buana), diikuti pejenengan lainnya seperti : Kober bergambar Anoman, Senjata Keris,dua buah Gelungan Legong, serta Ida Betara Ratu Ayu Mas Maketel (Rangda).

Ketika Upacara Piodalan Purnama Jiyesta di Pura Luhur Kanda Pat Sari Pangideran Dewata Nawa Sanggha, beliau medal napak pertiwi, menurut Yuniati (wawancara, 21 September 2019) mengatakan, beliau dipersembahkan banten : Tumpeng pitu, ajengan, biyukaonan, caru ayam berumbun, taler segan 33 tanding mengikuti warna maupun jumlah urip pangider-ider Dewata Nawa Sanggha. Arah Selatan warna merah 9 tanding, Barat warna Kuning 7 tanding, Utara warna Hitam 4 tanding, Timur warna Putih 5 tanding, dan di tengah-tengah warna Mancawarna 8 tanding. Demikian juga membuat Gegaluh sejumlah 33 buah, sesuai dengan jumlah pengurip-urip yaitu: Selatan Gegaluh 9 buah dengan kain Merah, Barat Gegaluh 7 buah dengan kain Kuning, Utara Gegaluh 4 buah dengan kain Hitam, Timur Gegaluh 5 buah dengan kain Putih, demikian juga di tengah Gegaluh 8 buah dengan kain manca warna. Berdasarkan jumlah segaan 33 tanding dan Gegaluh 33 pereraga, maka kemungkinan jumlah Widyadara dan Widyadari juga berjumlah 33 .

Menurut Gede Sudiarcana (wawancara, 29 September 2019), Sasolahan Legong Dedari menari melalui tahapa sesuai aturan tari Bali pada umumnya yaitu : pepeson, pengawak, pengecet, dan pekaad.

\section{Pepeson}

Pepeson adalah tahapan pertama menari diiringi tabuh pelegongan yang khas, ciptaan seke gong Banjar Pondok. Legong yang menari berjumlah 6 orang, masing-masing 3 orang penari legong warna Kuning, dan 3 orang warna Merah.

Pada tahapan kedua, 4 orang menari mengikuti tarian pertama, masing-masing 2 orang dengan costum warna Putih, dan 2 orang warna Hitam. Pada tahap ke tiga, 2 orang masing-masing memundut gelungan pajenengan yang disakralkan mengikuti tarian sebelumnya. Gerakan tari ngumbang ini, seolah-olah menyambut, menghormati kedatangan dua orang penari yang menggunakan gelungan pajenengan. Para penari sasolahan legong dedari sebagai symbol para widyadari-widyadara turun dari surga ini, bergerak lemah lunglai, lincah menyatu dengan alunan gamelan memberi kesan alam sorgawi. Dengan komposisi pengideran Dewata Nawa Sanggha, yaitu, duduk melingkar di bagian Utara menari dua orang penari dengan kostum warna Hitam, di bagian Timur dua orang yang menggunakan kostum berwarna Putih, tiga orang di bagian Selatan menari dengan kostum berwarna Merah, dan tiga orang menari di bagian Barat menggukan kostum berwarna Kuning, menari dengan sikap berdiri di tengah-tengah dua orang dengan kostum berwarna Hitam dan Putih. Jadi dalam gerakan pepeson dengan dua belas penari menggunakan property kipas sebagai ciri khas penari legong. Adegan pepeson seperti ini menjadi ekspresi seni tari khas, Sasolahan Legong Dedari di Banjar Pondok. Pada adegan pepeson ini, semua para pragina tari Legong Dedari, menari dengan mimic muka serta penjiwaan gerak tarinya sambil mengangkat oncer yang mencerminkan gerakan para Widyadari dan Widyadara yang turun terbang dari Kahyangan ke Bumi. Menurut Ariningsing (wawancara, 28 September 2019) mengakui bahwa, gerakan tari ini tiyang rasakan, yang paling 
baik,dan mantap diantara gerakan-gerakan yang pernah kami tarikan sejak Ida Sasuhunan metangi masolah sejak tahun 2016. Dimana gerakan ini sebagai hasil rekontruksi dari ISI Denpasar.Menurut Pujawan (wawancara, 21 September 2019), sekalipun direkontruksi oleh Tim ISI Denpasar, tarian legong dedari tetap sebagaimana konsep awal, dimana Sasolahan Legong Dedari tetap mengacu pada konsep sesuai konsep Pura Luhur Kanda Pat Sari Pengideran Dewata Nawa Sanga. ISI hanya memperindah gerak-gerik tarian, sehingga hasilnya dirasakan lebih baik, lebih indah dan estetik sesuai konsep satyam, siwam dan sundaram. Untuk jelasnya simak Gambar 1 dibawah ini.

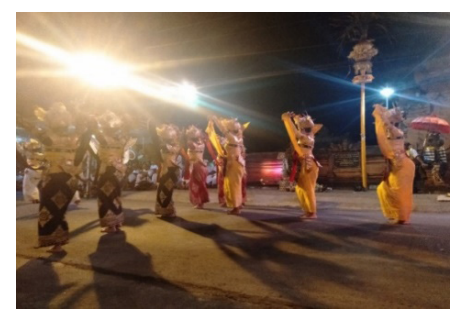

Gambar 1 Gerakan Ngumbang Para Penari Legong Dedari Foto Karya peneliti, 2019.

\section{Pengawak}

Pengawak merupakan gerakan penari Legong Dedari pada bagian tengah, yaitu, lanjutan dari gerakan tari bagian awal (pepeson). Pada gerakan pengawak ini para penari menari dengan jumlah 12 Orang. Tetuwek dapat diartikan bahwa gerakan penari legong sebagai karakter tari wanita cantik yang melambangkan gerakan Bidadari-Bidadara yang cantik, serta adanya gerakan berhadap-hadapan mencerminkan komunikasi diantara para Widyadari yang turun ke Bumi dengan raut muka yang ceria dengan ekspresi saling tukar senyum, sebagai pertanda saling tegur sapa. Gerakan pengawak tari Legong Dedari yang dilakukan berulang dua kali dengan komposisi yang berbeda. Di bagian akhir dari gerakan pengawak, dilakukan gerakan ngumbang yaitu gerakan berjalan ke depan dan akan dilanjutkan dengan gerakan pengecet. Untuk jelasnya simak gambar 2 dibawah ini.

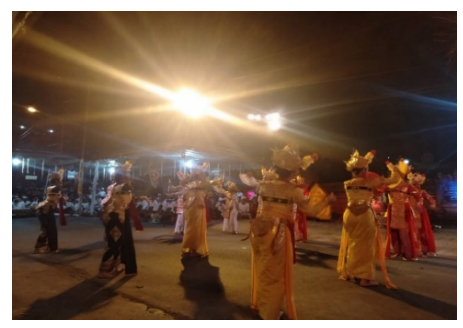

Gambar 2. Gerakan ngumbang Legong Dedari Foto karya peneliti, 2019

\section{Pengecet}

Pengecet pada tari Legong Dedari, merupakan kelanjutan dari gerakan pengawak, saling terkait merupakan alur gerakan yang seolah-olah berceritra, menceritrakan perjalanan para Widyadari -Widyadara dari alam Sunyaloka menuju alam sekala. Gerakan yang khas pada pengecet ini dimana para penari duduk melingkar dan didalam lingkaran menari berdiri dua orang penari yang memundut gelungan pajenengan, saat inilah di iringi dengan ilustrasi gending Sahyang Dedari, sebagai rekontruksi ISI Denpasar. Dengan dilantunkan suara Gending Sanghyang yang sayup-sayup merdu, seperti memanggil-manggil atau mengundang kehadiran para Widyadari-Widyadara untuk hadir dalam Sasolahan Legong Dedari, dialam Mayapada ini. Gending Sanghyang oleh gerong, betul-betul mampu berperan sebagai ilustrasi, menghiasi tarian legong dedari menjadi lebih estetik dari sebelumnya (direkontruksi) oleh ISI Denpasar.

Adapun syair gending Sanghyang Dedari adalah;

Gelung ye gelung agung

Mabulengker ye sekar gadung

Patitis geruda mungkur

Sekar sempol anggen nyelagin

Sandat gubang anggen susun

Tembang Jenar

Mengundang dedari agung

Sane becik Dewa undang

Sang Supraba Tunjung Biru

Dewu ayu dewi suci

Ida lunga mengendon ulangun

Mangungsi ke gunung sekar tetanaman bagus dedara

Mangulati sekar tunjung

Tunjung emas tunjung kuning

Lelakon sesapi mengimbang

Mengimbang sisin telaga mengimbangin I capung emas

Mekadi kekupu metarum

Selanjutnya dilakukan gerakan tari pemendak, dimana keduabelas penari berbaris rapi bergerak menuju arah medalnya Ratu Ayu Mas maketel(Rangda). Dua penari pemundut gelungan pajenengan menjemput Ratu Ayu Mas Maketel(Rangda) disertai iringan pajenengan kober bergambar Hanoman, pajenengan keris, bergabung menari bersama penari legong dedari yang lainnya. Ratu Ayu Mas Maketel (Rangda) menari ditengah-tengah diiringi oleh dua orang penari membentuk lingkaran bergerak murwa daksina yaitu Ratu Ayu Mas Maketel (Rangda) bergerak kearah kanan, sedangkan legong dedari bergerak kearah kiri. Ratu Ayu Mas Maketel (Rangda) menari dengan riangnya sambil melompat-lompat ringan, 12 orang penari tersebut duduk melingkar menghadap ketengah, dimana Ratu Ayu Mas Maketel (Rangda) menari melompat ringan sambil berucap-ucap, memutar kearah kiri dengan ucapan sebagai berikut:

Dadya ta pire pinten gati ..... kala nira gumeter ikanang pratiwi, apah, bayu, teja, akasa lintang tranggana muah ikang surya candra.

Mijil te sira Sang Hyang Siwa Pasupati, bipraya agendu rasa, bau rasa lawan ta sira WidyadaraWidyadari makabehan. Iiiiih ta kita Widyadari Supraba, Gagarmayang, Sulasih,Tunjung Biru, lan juga Widyadari 
Supeni enak te kita angededali lawaning yang yang in sinembah.

Terjemahannya:

Ketika beliau turun ke bumi, bumi terasa bergetar, bahkan terasa kesemua lapisannya dunia. Ketika itu Keluarlah Sang Hyang Siwa Pasupati, akan bertimbang rasa, bertatap muka, bertukar pikiran dengan Para Widyadara dan Widyadari semua, Hai engkau Widyadari Supraba, Gagarmayang, Sulasih, Tunjung Biru demikian juga Widyadari Supeni, tolong datang menghadap aku pujaanmu.

Selesai Ratu Ayu Mas Maketel berucapa-ucap mengajak semua Widyadari-Widyadara bertemu untuk bertimbang rasa sambil menari, maka semua penari berdiri menari berputar kearah berlawanan yaitu Ratu Ayu Mas Maketel bergerak memutar kearah Kiri, sedangkan para penari Legong Dedari bergerak memutar kearah kanan, dengan riang gembira selesai menari para penari legong Dedari kembali mengambil sikap duduk bersimpuh seperti semula untuk mendengarkan wejangan dari Ratu Ayu Mas Maketel (Rangda) dengan ucapan dibarengi gerakan melompat secara berurutan sebagai berikut:

Gerakan dan Ucapan Beliau ini meraga Siwa, di awali kearah Timur, dengan ucapan sebagai berikut :

Ah te kita buta kala petak warnan te, merangke-merangke, iki ana tadah saji, saturange manusanira, ayua kita anyengkala-anyengkali, yan wus kita amangan-anginum pemantukan ta kita maring purwa, menembah ta kita ring Sanghyang Iswara, mundur-mundur ta kita.

Terjemahannya:

Ah engkau buta kala putih warnanmu, mari-mari ini ada persembahan dari masyarakat, janganlah mengganggu masyarakat, silahkan nikmati hidangan ini, setelah selesai menikmati pulanglah kamu ketempatmu di timur, Sujud baktilah engkau kepada Sanghyang Iswara, Pergilah engkau.

Setelah beliau berucap sebagaimana di paparkan di atas, maka beliau bergerak dengan sigap melompat mengalihkan perhatian dan pandangan kearah Selatan dengan ucapan sebagai berikut:

Ih te kita buta kala bang warnan te,sewatekan segerekan rencangku pra samia, mabang rupania, merangkemerangke, iki ana tadah saji, saturange manusanira, ayua kita anyengkala-anyengkali, ayua kita angrebek, yan wus kita amangan-anginum pemantukan ta kita maring daksina, menembah ta kita ring Hyang Brahma, mundurmundur ta kita.

Terjemahannya:

Ih engkau buta kala merah warnanmu, semua para abdiku, mari-mari ini ada persembahan dari masyarakat, janganlah mengganggu masyarakat, silahkan nikmati hidangan ini, setelah selesai menikmati pulanglah kamu ketempatmu di Selatan, Sujud baktilah engkau kepada Hyang Brahma, pergilah engkau.

Selanjutnya beliau secara tidak sadar bergerak sontak melompat mengarahkan pandangan kearah Barat dengan ucapan sebagai berikut:

Uh te kita buta kala jenar warnan te,sewatekan segerekan rencangku pra samia, jenar rupania, merangke-merangke, iki ana tadah saji, saturange manusanira, ayua kita anyengkala-anyengkali, ayua kita angrebek, yan wus kita amangan-anginum pemantukan ta kita maring pascima, menembah ta kita ring Hyang Mahadewa, mundurmundur ta kita.

Terjemahannya :

Uh engkau buta kala Kuning warnanmu, semua para abdiku, mari-mari ini ada persembahan dari masyarakat, janganlah mengganggu masyarakat, silahkan nikmati hidangan ini, setelah selesai menikmati pulanglah kamu ketempatmu di Barat, Sujud baktilah engkau kepada Hyang Mahadewa, pergilah engkau.

Secara tidak sadar bergerak sontak melompat mengarahkan pandangan kearah Utara dengan ucapan sebagai berikut: Eh te kita buta kala ireng warnan te,sewatekan segerekan rencangku pra samia, ireng rupania, merangke-merangke, iki ana tadah saji, saturange manusanira, ayua kita anyengkala-anyengkali, ayua kita angrebek, yan wus kita amangan-anginum pemantukan ta kita maring uttara, menembah ta kita ring Hyang Wisnu, mundur-mundur ta kita.

Terjemahannya:

Eh engkau buta kala Hitam warnanmu, semua para abdiku, mari-mari ini ada persembahan dari masyarakat, janganlah mengganggu masyarakat, silahkan nikmati hidangan ini, setelah selesai menikmati pulanglah kamu ketempatmu di Utara, sujud baktilah engkau kepada Hyang Wisnu, pergilah engkau

Terakhir Ratu ayu Mas Maketel (Rangda) setelah berucap kea rah Utara, maka para penari Legong Dedari menari dengan sikap berdiri bergerak setengah memutar kearah kanan membentuk komposisi Ratu Ayu Mas Maketel (Rangda) di tengah menghadap ke Utara, sedangkan empat penari masing-masing berkostum warna Putih, Merah, Kuning, dan Hitam mendekat kedalam merapat disisi Ratu Ayu Mas Maketel membentuk posisi Bunga Teratai, Ratu Ayu Mas Maketel diposisi di tengah sebagai simbul Siwa diapit oleh empat penari yang masing-masing berwarna sesuai warna pangider-ider, sebagai simbul daun teratai yang mewakili empat penjuru arah yaitu; kangin, kelod, kauh, dan Kaja, serta yang ditengah-tengah adalah Ratu Ayu Mas Maketel sebagai Siwa Pasupati. Pada akhirnya para penari serentak sontak bersorak mintak menari lagi dalam keadaan trend (tidak sadar), suasana hening berubah 
menjadi misterius, mengerikan serta menakutkan, maka berakhir pulalah Sasolahan Legong Dedari dalam bentuk tari yang disebut pengecet. Untuk jelasnya simak gambar 3 dibawah ini.

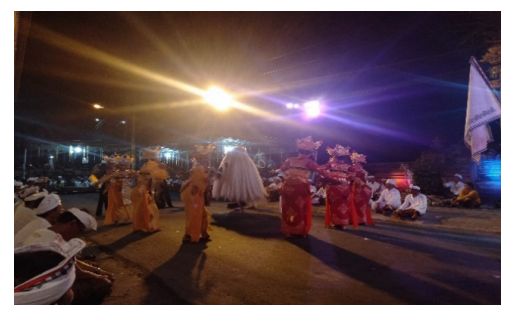

Gambar 3 Suasana Menjelang Kerauhan (Foto, karya peneliti, 2019)

\section{Pekaad}

Pekaad merupakan gerak tari terakhir dari rangkaian tari Bali umumnya dan khususnya Sasolahan Legong Dedari, Pada bagian akhir dari tari ini adalah, setelah selesainya tarian yang membentuk bunga teratai dimana Siwa berposisi di tengah-tengah yang diapit oleh empat penari Legong sebagai simbul empat penjuru mata angin, yaitu suasana berubah dari riang gembira menjadi hening sejenak, dan tiba-tiba suara gamelan terhenti, suasana mesteriuspun muncul dengan kerauhan para penari Legong Dedari yaitu bergerak ingin melanjutkan tariannya, dengan kata-kata masolah, masolah, masolah terlontar diucapkan secara tidak sadar oleh seorang penari yang memakai kostum warna Kuning, tapi apa daya gamelan telah berhenti dan para penaripun dipapah oleh para krama. Di dalam Pura para penari yang tidak sadarkan diri ini dipersembahkan banten penyineb di hadapan masing-masing pelinggih Pura Luhur Kanda Pat Sari Pangideran Dewata Nawa Sanggha, para penari diperciki tirta dan mulailah sadar sebagaimana biasa.

Untuk jelasnya Prosesi penyineban Sasolahan Legong Dedari simak gambar 4 di bawah ini.

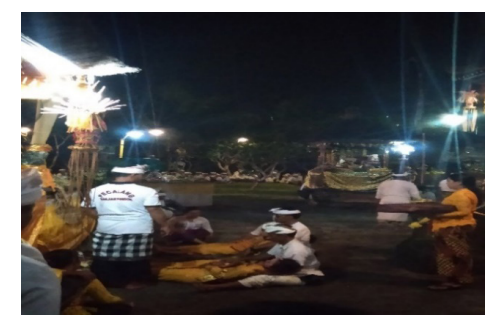

Gambar 4. Suasana penyineban (Foto karya peneliti, 2019)

Fungsi Sasolahan Legong Dedari Di Pura Luhur Catur Kanda Pat Sari Pengideran Dewata Nawa Sanggha.

Adapun fungsi Sasolahan Legong Dedari diuraikan sebagai berikut :

\section{Fungsi Religi.}

Sasolahan Legong Dedari hanya ditarikan ketika upacara piodalan di Pura Bale Banjar Pondok dan di Pura Luhur Kanda Pat Sari Pangideran Dewata Nawa Sanggha, oleh karena itu tergolong tari sacral.Ketika ditarikan wajib hukumnya melalui prosesi upacara penyucian, serta terjadinya trand ketika mengakhiri sasolahan. Sasolahan Legong Dedari memiliki kekuatan gaib yang bersifat niskala (abstrak) dihadirkan melalui dimensi sekala(nyata). Legong Dedari sebagai symbol para Bidadari yang turun dari suga ke bumi hadir dalam upacara piodalan dalam wujud tari legong dedari sebagaimana disampaikan oleh: Ariningsih (wawancara, 16 September 2019), pada saat saya menari tidak sadarkan diri, tetapi masih ingat akan apa yang saya rasakan ketika itu yaitu, saya merasakan diri sangat cantik, rambut saya mayang mengurai (nyapu jagat), dan berbau harum. Hal senada menurut Bintang (wawancara, 22 September 2019), ketika saya mulai memakai gelungan pajenengan yang disakralkan, saya merasa cantik seperti bidadari, gelungan yang ukurannya besar setelah saya pakai, sedikitpun tidak longgar,padahal sebelumnya terasa besar dan longgar. Demikian juga ketika Ida meraga Anoman rauh tedun, merasuki diri saya katanya saya melompat naik keatas umbul-umbul, banyak yang mengkhawatirkan saya jatuh, saya juga menggaruk-garuk tanah, setelah sadar saya periksa kuku saya sedikitpun tidak ada yang kotor atau robek, itulah keajaiban, yang sangat religius terjadi. Perilaku legong Dedari tersebut bukan sebagai ajang pamer kesaktian, namun sesungguhnya itu adalah sebuah even dari kekuatan Sang Hyang Widhi Wasa agar manusia menyadari bahwa beliau adalah Maha Segalanya.

Even Penyekalaan kekuatan yang Niskala tentunya akan berimplikasi pada meningkatnya keyakinan manusia akan kekuatan Sang Hyang Widhi Wasa. Demikian juga dapat menumbuh kembangkan kesadaran, bahwa manusia adalah sebagai makhluk yang religius sekaligus meyakini akan adanya Sang Hyang Widhi Wasa sebagai Yang Maha Segalanya. Keyakinan akan Sang Hyang Widhi Wasa adalah salah satu bagian dari Panca Sradha atau lima keyakinan elementer umat Hindu. Sebagai manusia yang religius, menjadi theistic adalah syarat yang sangat mutlak. Sebagaimana Rsi Patanjali dalam Yoga Sutra menyebutkan bahwa manusia hendaknya menjadi theistic sebelum melakukan hubungan degan Ida Sang Hyang Widhi Wasa (Saraswati, 2005 : 45). Pementasan Sasolahan Legong Dedari dapat dikatakan memiliki fungsi di dalam menumbuhkan kesadaran manusia sebagai makhluk religius yang meyakini Sang Hyang Widhi Wasa sebagai sumber segalanya, sebagaimana disebutkan dalam Brahma Sutra berikut :

Janmādyasya Yatah (Brahma Sutra.2)

Terjemahan :

Ida Sang Hyang Widhi Wasa adalah yang maha tahu dan penyebab yang mahakuasa dari mana munculnya asal mula dan lain-lain, Yaitu pemelihara dan peleburan dari dunia ini (Viresvarananda, 2004 : 71). 
Catra (2014 :27-28) dan Bandem (dalam Yasa, 2018:1), menegaskan, Bali yang mayoritas penduduknya memeluk agama Hindu, dimana ekspresi upaya mendekatkan diri kehadapan Tuhan dalam berbagai manifestasinya, dalam praktik beragama dilakukan melalui jalan "karmasandyasin" dan "yogasandyasin". Persembahan seni pertunjukan berupa seni suara,vocal/tembang/kidung, seni tari, seni tabuh menyatu luluh menjadi satu kesatuan dramatik ritual sebagai ekspresi budaya.

Bandem (2004:1) menegaskan, bahwa Tari Wali (Sasolahan Legong Dedari) sebagai tari sacral (wali) merupakan tari yang kental akan fungsi religius. Lekker (dalam Goris, 2012 : 1), menjelaskan masyarakat Bali mendapatkan penguatan yang tidak dapat dipatahkan akibat dari adanya aktifitas keberagamaan yang sudah tentu mendapat pengaruh yang kuat dari agama Hindu.

Realitas yang nyata-tidak nyata atau yang sementara-kekal di Bali dituangkan dalam konsep Sekala dan Niskala. Segala yang berkenaan dengan kekuatan gaib disimbolkan sebagai yang Niskala dan diidentikkan dengan sesuatu yang bersifat abstrak, yang manusia sendiri tidak dapat mendeskripsikan atau mendefinisikan. Bahkan pustaka suci Veda sendiri mendefinisikan yang gaib sebagai aspek dari sakti Sang Hyang Widhi Wasa, sehingga sulit manusia memahaminya. Terlebih dalam kitab Bhagavdgita dengan tegas menyebutkan bahwa Sang Hyang Widhi Wasa adalah bersifat Gaib dan kegaiban itu adalah Tuhan sendiri, seperti dalam sloka berikut :

Avinasi tu tad viddhi yena sarvam idam tatam,

Vinasam avyayasya na kascit kartum aharti.

(Bhagavadgita.II.17)

Terjemahan :

Ketahuilah bahwa Aku adalah gaib dan yang meliputi semuanya ini tidak dapat dimusnahkan. Terhadap keberadaan yang abadi ini, tidak seorangpun dapat memusnahkannya (Radhakrishnan, 2010 : 129).

Realitas yang nyata-tidak nyata atau yang sementara-kekal di Bali dituangkan dalam konsep Sekala dan Niskala. Segala yang berkenaan dengan kekuatan gaib disimbolkan sebagai yang Niskala dan diidentikkan dengan sesuatu yang bersifat abstrak, yang manusia sendiri tidak dapat mendeskripsikan atau mendefinisikan. Bahkan pustaka suci Veda sendiri mendefinisikan yang gaib sebagai aspek dari sakti Sang Hyang Widhi Wasa, sehingga sulit manusia memahaminya. Terlebih dalam kitab Bhagavdgita dengan tegas menyebutkan bahwa Sang Hyang Widhi Wasa adalah bersifat Gaib dan kegaiban itu adalah Tuhan sendiri, seperti dalam sloka berikut :

Avinasi tu tad viddhi yena sarvam idam tatam,

Vinasam avyayasya na kascit kartum aharti.

(Bhagavadgita.II.17)
Terjemahan :

Ketahuilah bahwa Aku adalah gaib dan yang meliputi semuanya ini tidak dapat dimusnahkan. Terhadap keberadaan yang abadi ini, tidak seorangpun dapat memusnahkannya (Radhakrishnan, 2010 : 129).

Sloka dalam Bhagavadgita tersebut di atas memberikan pemahaman bahwa kekuatan gaib adalah Sang Hyang Widhi Wasa dan kekuatan tersebut tidak akan dapat dimusnahkan. Dengan kata lain kekuatan gaib ini kekal adanya. Di samping itu kegaiban adalah salah satu dari aspek Sang Hyang Widhi Wasa, disebutkan dalam Tattwajñana sebagai berikut :

..., Atmikatattwa adalah Sadasiwatattwa yang "utaprota" dalam Mayatattwa (Acetana). Uta artinya Tuhan berada secara gaib dalam Mayatattwa bagaikan api dalam kayu. Prota artinya Tuhan berkeadaan bagaikan permata cemerlang dalam Mayatattwa,....(Tim Penyusun, 2005 : 18).

Penggalan teks dalam Tattwajñana tersebut di atas dengan jelas menyebutkan bahwa Sang Hyang Widhi Wasa secara gaib berada dalam realitas yang bersifat maya ini. Dengan kekuatan yang maha gaib, Sang Hyang Widhi Wasa menyusupi segalanya, memberikan kehidupan pada seluruh entitas kehidupan. Kekuatan gaib yang merupakan aspek Sang Hyang Widhi Wasa inilah yang diejawantahkan dalam Sasolahan Legong Dedari sehingga dapat memunculkan sisi religiusitas manusia, khususnya masyarakat di Banjar Pondok. Terlebih Sasolahan Legong Dedari sangat kental dengan segala sesuatu yang bersifat gaib.

\section{Fungsi Penyucian}

Sedangkan disisi lain penyakit dan kematian itu bisa terjadi, pasti ada penyebabnya, sesuai hukum sebab, akibat. Mengenai hal ini menurut pandangan Samkya Darsana menyebutkan bahwa, ada tiga sumber penyakit yang mendatangkan penderitaan, yaitu:

1. Adhyatmika, yaitu penderitaan yang disebabkan oleh virus, kuman dan sejenisnya.

2. Adhidaivika, yaitu penyakit yang datang dari alam, cuaca dan yang lainnya.

3. Adhibauthika, yaitu penyakit yang datang oleh binatang dan yang muncul dari kelahiran (Sivananda, 2003: 193).

Ketiga penyakit yang berimplikasi pada penderitaan tersebutlah akibat dari ketidakseimbangan antara dua kekuatan negatif dan positif tersebut. Berdasarkan pada hal tersebut, sangat penting menetrailisir atau nyomya kekuatan tersebut melalui pementasan Sasolahan Legong Dedari, dimana Ida Sasuhunan yaitu Ratu Ayu Mas Maketel tedun napak pertiwi dalam acara ngerebeg, Tumpek Wayang dan Purnama Jiyesta, yaitu acara mececingak, ketika sasih panes atau sasih keenem, acara Piodalan 
Beliau dan acara Piodalan di Pura Luhur Catur Kanda Pat Sari Pangideran Dewata Nawa Sanggha. Dimana Ida Sasuhunan lunga mececingak sewilayah Banjar Pondok Nyatur Desa bertujuan untuk mengusir kekuatan negatif yang kemungkinan akan dapat mengganggu kenyamanan masyarakat banjar Pondok, sebagaimana yang diucapkan oleh Beliau ketika tedun masolah dalam kaitannya dengan Upacara Piodalan di Pura Luhur Kanda Pat Sari Pangideran Dewata Nawa Sanggha yaitu: Beliau yang mapelawatan Rangda sebagai Siwa Pasupati mengucapkan sebagai berikut;

Ketika beliau Ratu Ayu Mas Maketel menghadap kearah Timur dengan ucapan sebagai berikut :

Ah te kita buta kala petak warnan te, merangke-merangke, iki ana tadah saji, saturange manusanira, ayua kita anyengkala-anyengkali, yan wus kita amangan-anginum pemantukan ta kita maring purwa, menembah ta kita ring Sanghyang Iswara, mundur-mundur ta kita.

Terjemahannya:

Ah engkau buta kala putih warnanmu, mari-mari ini ada persembahan dari masyarakat, janganlah mengganggu masyarakat, silahkan nikmati hidangan ini, setelah selesai menikmati pulanglah kamu ketempatmu di timur, Sujud baktilah engkau kepada Sanghyang Iswara, Pergilah engkau.

Setelah beliau berucap sebagaimana di paparkan di atas, maka beliau bergerak dengan sigap melompat mengalihkan perhatian dan pandangan kearah Selatan ditujukan kepada Dewa Brahma, kea rah Barat kepada Dewa Hyang Maha Dewa, kearah Utara ditujukan kepada Dewa Wisnu.

Dari ucapan ketika beliau berperan sebagai Siwa Pasupati dan menghadap keseluruh penjuru mata angin yaitu ke Timur, ke Selatan, ke Barat, dan ke Utara, beliau memanggil dan mengajak semua buta kala sebagai abdi beliau yang setia, untuk datang menghadap beliau untuk bersama-sama berkompromi, berdemokrasi, sambil menikmati persembahan masyarakat berupa sesaji, setelah menikmati, jangan lagi mengganggu ketentraman, kenyamanan, serta keselamatan masyarakat, dan beliau memerintahkan kepada para Bhuta Kala semua agar tetap sujud bhakti kepada Dewanya masing-masing. Menyimak hal ini, maka Sasolahan Legong Dedari disamping diyakini keberadaannya juga beliau berperan nyomya para bhuta kala, agar berubah sifat dan karakter bhutakalanya menjadi Dewa, yang memberikan pengayomam, perlindungan, serta kesejahtraan manusia. Sehingga masyarakat terhindar dari segala bentuk gangguan berupa wabah penyakit seperti : gering yaitu, jenis penyakit yang mematikan bagi mahluk hidup jenis manusia, gerubug atau sasab yaitu, jenis penyakit yang mematikan bagi mahluk hidup jenis hewan, dan merana merupakan jenis penyakit yang mematikan bagi mahluk hidup jenis tumbuh-tumbuhan.

Jika hal ini sudah tidak terjadi lagi maka keseimbangan
Bhuana Agung dan Bhuana Alit akan terwujud, sebagai salah satu implikasi dari Sasolahan Legong Dedari. Hal ini sangat diyakini oleh masyarakat banjar Pondok sebagai penetralisir kekuatan negatif menuju keseimbangan.

\section{Fungsi Sosial}

Menurut Atmaja (2010 : 196), manusia sesungguhnya adalah makhluk sosial yang tidak dapat hidup sendiri. Interaksi sosial dibutuhkan oleh manusia agar manusia dapat hidup, sebab manusia hidup saling membutuhkan dan saling bergantung antara satu dengan yang lainnya. Tidak saja sesama manusia, kepada alam juga manusia saling ketergantungan, sebab manusia tidak akan dapat hidup tanpa alam demikian juga sebaliknya. Banyak bidang kegiatan yang dapat menunjukkan dan menjalin hubungan sosial yang baik, terlebih di Bali banyak terdapat aktifitas yang dapat memunculkan rasa solidaritas sosial. Bali sendiri dikenal dengan sistem adat yang disebut Desa Pakraman sudah barang tentu sebagai wadah interaksi sosial antara krama Bali dan sebagai pembertahanan Hindu. Segala aktifitas terutama aktifitas keberagamaan selalu dilakukan dalam ruang lingkup Desa Pakraman yang menyebabkan kerukunan antar masyarakat Hindu Bali. Sebagaimana dikatakan Wiana (2004: 78), bahwasanya kerukunan sosial Hindu di Bali tidak dapat dipisahkan dari aktifitas keberagamaan yang dilakukan di setiap desa dengan landasan ajaran agama Hindu tentunya. Berdasarkan pada hal tersebut, banyak aktifitas keagamaan di Bali yang memiliki fungsi sebagai media dalam menumbuhkan kerukunan sosial. Pandangan di atas sesuai dengan apa yang dikatakan oleh Widya Kusuma sebagai Kelian Adat Banjar Pondok (wawancara, 7 September 2019) ;

Sejak beliau Ratu Ayu Mas Maketel ditarikan, masyarakat banjar Pondok saat ini mau bersatu, dan erat sekali, apapun yang direncanakan di banjar disepakati, untuk membangkitkan kembali Sasolahan Legong Dedari ini pun masyarakat sangat antosias, serta menghabiskan biaya yang tidak sedikit, tetapi anehnya ketika kita membuat pertanggungjawaban tiba-tiba ada sisa uang lagi dua puluh juta rupiah, saya tidak mengerti dari mana datangnya uang sejumlah itu, makanya masyarakat tidak berani lagi mainmain, apapun rencananya asal untuk kepentingan Ida Sasuhunan Masolah Napak Pertiwi diiringi Sasolahan Legong Dedari pasti sepakat. Kalau dulu sebelumnya Ida Masolah Napak Pertiwi tidak mau seperti ini.

Menyimak penomena di atas, maka Sasolahan Legong Dedari sangat berperan dalam meningkatkan kehidupan sosial masyarakat khususnya masyarakat banjar Pondok, dari awalnya masyarakat yang kondisinya agak susah dalam aktifitas sosial masyarakat, maupun sosial keagamaan, dan berkat Sasolahan Legong Dedari dibangkitkan kembali masyarakat menjadi semakin sadar akan segala bentuk kegiatan sosial kemasyrakatan, maupun sosial keagamaan sangat dibutuhkan untuk keharmonisan kehidupan bermasyarakat. 


\section{Fungsi Estetika}

Estetika Hindu pada intinya merupakan cara pandang mengenai keindahan (lango) yang diikat oleh nilai-nilai agama Hindu yang didasarkan atas ajaran-ajaran kitab suci Weda. Ada beberapa konsep yang kiranya menjadi landasan penting dari estetika Hindu. Konsep-konsep yang dimaksud antara lain konsep kesucian, konsep kebenaran, dan konsep keseimbangan. Dalam agama Hindu disebut dengan istilah Tiga Wisesa, yaitu :

1. Sivam (Konsep kesucian), yaitu pada intinya menyangkut nilai-nilai ketuhanan yang juga mencakup yajna dan taksu.

2. Satyam (kebenaran), yaitu mencakup nilai kejujuran, ketulusan, dan kesungguhan. Sesuai dengan ajaran agama Hindu, persembahan dan yajña yang dilakukan oleh masyarakat Hindu seyogianya dilaksanakan dengan penuh kejujuran hati, rasa tulus, dan niat yang sungguh-sungguh.

3. Sundaram (Keindahan), yaitu pada konteks teori khusus (local theory) seperti yang dijelaskan di atas, maka kepuasan estetik baru akan terpenuhi jika telah terjadi keselarasan dan harmonis (Djelantik,1999: 20). Sebagai penumbuh kekuatan semua itu dilandasi oleh konsep tiga wisesa yakni satyam, çiwam, sundaram; sebuah keindahan yang suci untuk penghayatan kepada Ida Sang Hyang Widhi Wasa dan secara etika benar atau mengandung kebenaran dalam artian dalam sebuah pesan. Bertumpu pada uraian tersebut di atas, Sasolahan Legong dedari yang berada di Banjar Pondok, Peguyangan Kaja Denpasar dalam kaitannya dengan Piodalan : Tumpek Wayang, Ngerebeg, Piodalan di Pura Luhur Kanda Pat Sari Pangideran Dewata Nawa Sanggha dapat dikatakan sarat akan fungsi estetika sebagai symbol dari struktur konsep Pura Luhur Kanda Pat Sari Pengideran Dewata Nawa Sanga. Dalam prosesi maupun pada saat ditarikan oleh pemundut, Sasolahan Legong Dedari memiliki konsepsi Satyam, Siwam, Sundaram.

\section{Makna Simbol Sasolahan Legong Dedari Di Pura Luhur Catur Kanda Pat Sari Pengideran Dewata Nawa Sanggha.}

Makna dalam setiap aktifitas keberagamaan di Bali dan khususnya Sasolahan Legong Dedari, tidak dapat dipisahkan dari hakekat yang ada di dalamnya, yaitu:

\section{Makna Religius}

Mendeskripsikan tentang makna religius dalam tari Sasolahan Legong Dedari di Banjar Pondok dalam upacara Tumpek Wayang, Ngerebeg dan Upacara Piodalan di Pura Luhur Catur Kanda Pat Sari Pangideran Dewata Nawa Sanggha, Desa Adat Peguyangan Kaja, religius = tattwa dalam agama Hindu. Tattwa = filsafat. Subagiasta (2007 : 6), menyebutkan kata Tattwa berasal dari bahasa Sansekerta, yaitu dari akar kata Tat yang artinya hakikat, kebenaran, kenyataan, sari-sari ajaran, dan kata Twa artinya yang bersifat. Jadi, kata Tattwa adalah hakikat atau kebenaran, suatu unsur baik yang nyata maupun yang tidak nyata atau hakikat dari Hyang Widhi. Nurkancana (2005: 5), menegaskan Tattwa berarti hakikat, atau kenyataan yang sesungguhnya. Kebenaran sejati itulah yang menurut Gandhi (dalam Suwantana, 2006 : 9), disebut dengan Tuhan Yang Maha Esa.

Bersandarkan pada Tattwa sebagai hakikat kebenaran sejati, maka dapat dipastikan bahwa Sasolahan Legong Dedari terkandung makna Tattwa. Kehadiran kekutan Tuhan dapat dilihat pada Sasolahan Legong Dedari, sebagai simbol manivestasi beliau secara nyata dapat menunjukan karakter atau sifat-sifat para Dewa yang turun ke bumi melalui para penari tersebut. Sebagaimana dinyatakan oleh, Bintang (wawancara, 22 Sepetember 2019), ketika saya melompat dan naik ke atas umbul-umbul sampai tinggi saya rasakan ringan sangat gampang memanjat umbulumbul yang kecil dan tinggi. Berdasarkan penjelasan informan di atas maka secara tidak sadar seketika itu juga, badan dikendalikan oleh kekuatan yang maha hebat, itulah kekuatan spirit rohani Tuhan yang merangsuki penari. Menguatkan hal tersebut, dapat dicermati delapan kemaha kuasaan Tuhan atau disebut Astaaiswarya dalam Wrehaspati Tattwa berikut :

Hana anima nagaranya, hana laghima nagaranya, hanamahima nagaranya, hana prapti nagaranya, hana prakamya ngaranya, hana isitva ngaranya, hana vasitva nagaranya, hana yatrakamavasitva nagaranya..., (Wrehaspati Tattwa. 66)

\section{Terjemahan :}

Ada yang disebut anima (kekuatan Tuhan Siwa dapat menjadi sekecil-kecilnya), laghima (ringan seringanringanya), mahima (besar sebesar-besarnya melampui segalanya), prapti (sukses selalu), prakamnya (terwujud segala keinginan), isitva (maha pengatur), vasitva (kemaha kuasaan) dan yatrakamavasitva (maha kehendak) dan itulah delapan aisvarya atau kekuatan gaib dari Tuhan...., (Putra, 1998 : 68).

Menurut Ariningsih (wawancara, 16 September 2019), pada saat tiyang mulai dimasuki kekutan gaib, tiyang merasakan diri tiyang cantik sekali, rambut tiyange lantang melembad nyapu jagat, awak tiyang berbau harum, atau miik pokokne. Mencermati apa yang disampaikan oleh Ariningsih, bahwa kehadiran kekuatan gaib tersebut adalah suatu kekuatan gaib sebagai manifestasi Ida Sanghyang Widhi dalam Prabawanya sebagai WidyadaraWidyadari. Menurut Sri Mpu Acarya Nanda (wawancara, 21 September 2019) dalam lontar Aji Turus Tunjung dalam konsep Pengideran Dewata Nawa Sanggha disebutkan : di Timur Widyadarinya adalah Widyadari Dewi Supraba, berwarna Putih, di Selatan, Widyadari Gagar Mayang, berwarna Merah, di Barat Widyadari Ken Sulasih, berwarna Kuning, di Utara Tunjung Biru, berwarna Hitam, di Tengah-tengah Widyadarinya adalah, Sang Supeni, dalam Sasolahan Legong Dedari diperankan dalam wujud Rangda sebagai simbol Ida Ratu Ayu Mas Maketel, atau 
simbol Siwa Pasupati.

\section{Makna Penyucian}

Sasolahan Legong Dedari dalam kaitannya dengan Upacara Piodalan Tumpek Wayang yang dilaksanakan di Bale Banjar Pondok, Ngerebeg sasih keenem nyatur Desa, dan Piodalan di Pura Luhur Kanda Pat Sari Pangideran Dewata Nawa Sanggha, dimana Ida Ratu Ayu Mas Maketel tedun Napak Pertiwi, berkeliling ke arah kiri sebanyak tiga kali disertai memercikan tirta keseluruh arah yang dilaluinya, ini juga merupakan implementasi simbol penyucian buana agung. Demikian juga menjelang menari, semua penari wajib hukumnya untuk mengikuti upacara penyucian ini sebagai simbol untuk menyucikan buana alit.

Ida Ratu Ayu Mas Maketel yang mapelawatan Rangda, gelungan pajenengan yang disakralkan juga diperciki Tirtha Wangsuh Pada Hyang Widhi (Ida Betara), diminum dan meraup (mencuci muka). Prilaku ini sebagai symbol, agar pikiran dan hati kita menjadi bersih dan suci yaitu bebas dari segala kotoran, noda dan dosa, kecemaran dan sejenisnya. Sebagaimana disebutkan oleh Wiana (2005 : 83), Tirtha ini berfungsi untuk membersihkan diri dari kotoran maupun kecemaran pikiran. Adapun pemakaiannya adalah dipercikkan di kepala, diminum dan diusapkan dimuka. Ini merupakan simbolis pembersihan bayu, sabda dan idep. Untuk kekuatan Tuhan dapat berada dalam diri, demikian pula sinar Atman supaya dapat menerangi pekiran, budhi dan ahamkara, tubuh hendaknya disucikan terlebih dahulu. Kekawin Arjuna Wiwaha menganalogikan, seperti air pada tempayan yang bersih bayangan bulan akan tampak demikian juga jika tubuh disucikan sinar Ida Sang Hyang Widhi Wasa akan jelas terlihat. Berikut petikan bait kekawin tersebut:

Sasi Wimba haneng ghata mesi banyu

Ndan asing suci nirmala mesi wulan

Iwa mangkana rakwa kiteng kadadin

Ring angembeki yoga kiteng sakala

(Arjuna Wiwaha. 11.1)

Terjemahan :

Diibaratkan seperti bayangan bulan yang nampak pada tempayan yang berisi air yang jernih maka bayangan bulan akan jelas terlihat. Demikian pula jika kesucian dalam diri maka Tuhan akan selalu hadir dalam diri, demikianlah hidup yoga sebenarnya (Tim Penyusun, 2006 : 5).

Bertitik tolak pada bait kekawin tersebut, dapat dimaknai bahwasanya kesucian adalah sangat penting untuk menghadirkan Tuhan sebagai yang suci dalam Buana Agung (alam semesta) maupun Buana Alit (diri manusia). Sebagaimana Narayana (2006: 9), menyebutkan bahwa yang suci hanya akan dapat disentuh oleh kesucian itu sendiri.

\section{Makna Sosial}

Aktifitas keberagamaan bagi masyarakat Bali khusunya agama Hindu tidak dapat dipisahkan dari etika atau Susila itu sendiri. Etika sangat memegang peranan penting di dalam umat Hindu menghubungkan diri dengan Tuhan. Dalam menghubungkan diri dengan Tuhan, umat Hindu dapat menempuh banyak jalan atau cara, sebagaimana ditekankan dalam Bhagavadgita sebagai berikut:

Ye yathā mām prapadyante tāms tathaiva bhajāmy aham, Mama vartmānuvarthante manusyāh pārtha sarvaśyah. (Bhagavadgita, IV. 11)

Terjemahan :

Jalan apapun orang memuja-Ku, pada jalan yang sama Aku memenuhi keinginannya, wahai Partha, karena semua jalan yang ditempuh mereka, semuanya adalah jalan-Ku (Maswinara, 1999 : 234).

Berdasarkan pada hal tersebut di atas, maka umat Hindu memiliki keragaman bentuk dalam menghayati Tuhan. Keberagaman itu, secara keseluruhan adalah sebagai bentuk bhakti umat kepada Tuhan. Keberagaman itu dapat dilihat dengan adanya beragam bentuk yajna, dan dalam setiap yajna aspek etika atau Susila tidak dapat dipisahkan. Susila adalah sesutau yang penting bagi umat Hindu dalam melakoni kehidupan, terlebih dalam rangka menghubungkan diri dengan Tuhan, Susila adalah syarat yang harus dipenuhi. Sebab pada hakikatnya, agama Hindu bersandar pada dharma sebagai sebuah rule untuk menjalani kehidupan. Etika atau Susila dalam agama Hindu sendiri dapat diterminologikan sebagai aturan tingkah laku yang baik (Atmaja, 2010: 11). Senada dengan itu Ngurah, (1999: 1), menjelaskan bahwa etika tidak saja milik satu dua orang atau golongan. Tetapi, etika adalah milik setiap kelompok masyarakat, dengan etika, kelompok masyarakat diharapkan akan mempunyai tata makna untuk mengatur hidup bersama.

Makna sosial ini tersirat dalam Sasolahan Legong Dedari antara lain :Pertama, selama Sasolahan Legong Dedari ditarikan, maka para penari maupun masyarakat setempat tidak ada yang berani mengucapkan kata-kata kotor. Semua masyarakat diam, hening kecuali nyanyian gerong, tandak, serta suara gamelan yang mengiringi Sasolahan Legong Dedari sebab tarian ini adalah tarian yang sacral (tari wali). Kata-kata yang kasar dan menyinggung perasaan orang lain yang dapat menyebabkan Sasolahan Legong Dedari terkontaminasi, apalagi dapat menyebabkan orang lain menderita akan menimbulkan hasil yang tidak baik pula, sebagaimana dalam Silakrama disebutkan:

Washita nimitanta manemu mitra

Washita nimitanta manemu laksmi

Washita nimitanta manemu dukha

Washita nimmitanta pati kapangguh.

(Silakrama, 9) 
Terjemahan :

Karena ucapan mendapatkan sahabat, karena ucapan mendapatkan kesejahteraan, karena ucapan mendapatkan penderitaan dan karena ucapan mendapatkan kematian (Tim Pnyusun, 1999: 10).

Ungkapan dalam Silakrama tersebut dengan jelas menyebutkan bahwa ucapan dapat mendatangkan penderitaan di dunia. Sasolahan Legong Dedari secara tindak langsung mengajarkan masyarakat untuk mengendalikan ucapan. Dengan diam, masyarakat diajarkan untuk focus dan memusatkan pikiran untuk menghadirkan kekuatan yang suci dari Ida Sang Hyang Widhi Wasa, sehingga dengan kuasanya Tuhan dapat memberikan waranugraha kepada masyarakat serta terhindar dari segala gangguan.

\section{Makna Estetika}

Estetika Hindu pada dasarnya merupakan cara pandang mengenai rasa keindahan (lango atau kalangwan), istilah yang dipakai oleh para kawi zaman dahulu, yang dilihat dari makna agama Hindu yang didasarkan atas ajaran kitab suci Veda. Berkaitan dengan uraian tersebut, maka beberapa konsep yang menjadi landasan penting dari estetika Hindu yakni konsep kesucian, konsep kebenaran dan konsep keseimbangan. Dalam konsep estetika Hindu di Bali khususnya terdapat di dalam konsep tiga wisesa, yaitu : satyam (kebenaran), siwam (kesucian), sundaram (keindahan) (Djelantik, 1999 : 58).

Hindu yang dipentingkan adalah sebuah dialektika yang selalu menempatkan kebenaran itu suci dan indah, serta keindahan itu harus suci dan mengandung kebenaran. Berdasarkan pada hal tersebut, dalam berbagai wujud kegiatan agama, seni dan budaya tidak dapat dipisahkan. Hampir dalam setiap ritual Yajna diiringi dengan kesenian yang memunculkan kesan estetik. Kesenian ini secara tidak langsung dapat disajikan kepada invisible audience (Tuhan), dan semua jenis kesenian yang merupakan persembahan kepada tuhan dikategorikan sebagai kesenian sakral. Semua jenis kesenian yang merupakan sajian kepada sesama manusia dikategorikan sebagai kesenian sekuler. Patut dicatat bahwa dalam derajat tertentu semua kesenian ini memiliki kekuatan spritual hanya ruang dan tempat penyajiannya mempunyai kualitas "spritual" yang berbeda. Demikian juga kesemuanya itu memunculkan makna estetik tersendiri. Sasolahan Legong Dedari sebagai salah satu tari sakral di Bali memiliki juga makna estetik yang dalam, sebab setelah dilakukan rekontruksi oleh ISI Denpasar disamping diperindah struktur dan gerak tarinya juga menambahkan gending Sanghyang oleh gerong dan sesendon oleh Dalang. Alunan Gending Sanghyang tersebut disamping menambah kesan idah sekaligus magis, membuat semakin terpesona. Sasolahan Legong Dedari dengan ilustrasi gending sanghyang irama sayup-sayup merdu, menyedihkan membuat masyarakat terhipnotis oleh keindahan nyanyian tersebut. Nyanyian atau Gending sendiri sesunguhnya sudah ada dalam Veda, seperti dalam beberapa mantram berikut : Gayo sasra wartani,... artinya; Kami menyanyikan mantra-mantra Sama Weda dalam ribuan...(Titib, 2003 : 54). Kitab Reg Weda Mandala II menyatakan tentang pentingnya seni olah vokal dalam melaksanakan upacara agama, seperti dalam mantram berikut :

Pradaksinid abhi grnanti karavo

Vayo vadanta rtuthā sukhantayah

Ubhe vacau vadati sāmagā iva

Gayatram ca traistubhyam cānu rājati.

(Reg Weda II.43.1)

Terjemahan:

Semoga burung-burung dari suara hati nurani membimbing kami selamanya dalam menyatakan sekitar perjalanan sesuai dengan lingkungan, seperti penyanyi lagu pujian yang cerdik menyatakan tentang kedua jenis pujian seperti penyanyi saman setelah menguasai metrum-metrum gayatri, usnik, tristyubh, dan jagati (Titib, 2003: 335).

Kitab Reg Weda Mandala IX juga menyatakan pentingnya seni suara untuk memperindah suasana.

Sakhāya āmi sldata punāya

Pragayata śiśum nayajňaih pari

Bhüsata śriye.

(Reg Weda, IX.104.1.615)

Terjemahan :

Ber-stana-lah wahai sahabat, bernyanyilah bagi Soma yang telah disaring itu, menghiasi dengan menawarkan untuk memperindah suasana, seperti orang tua yang menghiasi seorang anak (Titib, 2003: 356).

Bertitik tolak dari beberapa mantram Veda tersebut di atas, maka nyanyian adalah dimuliakan dalam Veda, terlebih itu nyanyian suci Sanghyang untuk menghadirkan kekuatan suci Tuhan melalui media Sasolahan Legong Dedari, Gending Sanghyang yang dinyanyikan oleh gerong memunculkan keindahan atau estetika yang luar biasa. Demikian juga media gending tersebut secara tidak langsung dapat dijadikan media estetik dalam memaknai keindahan yang sudah tentu tidak dapat terlepas dari makna satyam atau kebenaran, sivam atau kesucian, dan sundaram atau keindahan (keharmonisan) itu sendiri.

\section{SIMPULAN}

Sasolahan Legong Dedari sebagai tari Wali (sacral) prosesi merupakan suatu kewajiban yang tidak dapat ditawartawar lagi, oleh karena itu Sasolahan Legong Dedari, menari merupakan kewajiban yang mesti dilakukan dalam mengemban tugas sebagai penari yang didasari atas penuh rasa Sradha dan Bhakti kehadapan Ida Ratu Ayu Mas Maketel, melalui tahapan-tahapan proses penyucian yang dilengkapi dengan sarana upakara (banten). Sasolahan Legong Dedari memiliki yaitu fungsi : Religi, Penyucian, 
fungsi, dan Estetika. Sasolahan Legong Dedari tersirat makna: religious, penyucian, sosial, dan estetika.

\section{DAFTAR RUJUKAN}

Atmaja, Nengah Bawa. 2010. Ajeg Bali Gerakan Identitas Kultural dan Globalisasi. Yogyakarta : LKIS.

Bandem, I Made. 2004 .Etnologi Tari Bali. Yogyakarta : Kanisius (Anggota IKAPI).

Catra, I Nyoman.2014. Tinjauan Aspek Seni Joged Pingitan dan Baris Upacara (Makalah disampaikan dalam Rangka Pelaksanaan Workshop dan Lokakarya Joged Pingitan dan baris Upacara) Diselenggarakan oleh LISTIBYA Prov. Bali Denpasar. Tanggal 26 s/d 28 November 2014.

Duija, I Nengah.2019. Prasi :Karya Kreatif Estetik Unggulan Bali (Sebuah Studi Teo-Antropologi).Mudra Jurnal Seni Budaya. Denpasar : LP2M Institut Seni Indonesia Denpasar.

Djelantik, A.A. Made.1999. Estetika Sebuah Pengantar. Bandung : Masyarakat Seni Pertujukan Indonesia.

Goris, R. 1954. Bali,Atlas Kebudayaan.Jakarta.

Yasa, I Ketut. 2018. Seni dan Agama.Surakarta: Pustaka Exspresi.

Subagiasta, I Ketut. 2007. Tattwa Hindu. Surabaya : Paramita.

Saraswati, Sri Chandrasekharendra. 2005. Peta Jalan Veda. Jakarta : Media Hindu

Suwantana, I Gede. 2006. Gandhi da Doa. Denpasar : Ashram Gandhi Puri.

Suhardana.K.M, 2015. Ensiklopedia Pura (23 Pura di Kompleks Pura Besakih dan 53 Pura di Bali, Jilid I. Surabaya : Paramita.

Sugriwa, I Gusti Bagus. 1952.”Seni Budaya Bali” dalam Majalah Kebudayaan Edisi Indonesia Nomor Bali.Jakarta : Lembaga Kebudayaan Indonesia

Titib, I Made , 2003. Teologi dan Simbol-Simbol dalam Agama Hindu. Surabaya : Paramita.

Tim Penusun. 2006. Kakawin Arjuna Wiwaha. Denpasar : Dinas Kebudayaan.

Maswinara. 1999. Bhagavadgita. Surabaya : Paramita
Mantra, Ida Bagus. 1991.Landasan Kebudayaan Bali. Denpasar : Yayasan Dharma sastra.

Ngurah, I Gusti Made. dkk. 1999. Buku Pendidikan Agama Hindu Untuk Perguruan Tinggi. Surabaya : Paramita

Putra, Ny. I.G.A. Mas, 1998. Wrehaspati Tattwa. Surabaya : Paramita.

Wiana, I Ketut, 2004. Mengapa Bali Disebut Bali. Surabaya : Paramita.

Wiana, I Ketut, 2005. Fungsi Sarana Persembahyangan. Surabaya : Paramita.

Wiana, I Ketut. 2014. "Meningkatkan Daya Guna Agama Membangun Keluhuran Moral dan Daya Tahan Mental" Makalah Dharma Wacana Mapolda Bali.

Vireswarananda, Swami. 2004. Brahmasutra. Surabaya : Paramita.

\section{DAFTAR INFORMAN}

Nama : Dr. Drs. I Wayan Miarta,

M.Ag (Pandita Sri Empu Acarya Nanda)

Tanggal Lahir/Umur : 56 Tahun

Jenis Kelamin : Laki-laki

Alamat : : Serongga, Lebih, Gianyar

Pekerjaan : Dosen, Pandita

Nama $\quad$ : Ratu Niang Mangku

Tanggal Lahir/Umur : : 70 Tahun

Jenis Kelamin : : Perempuan

Alamat : Banjar Pondok, Peguyangan

Kaja,(Sebelah Timur Pura Luhur)

Pekerjaan : Pemangku Gede,Pura

LuhurCatur Kanda Pat Sari Pangideran Dewata Nawa

Sanga

Nama

: I Made Ruda

Tanggal Lahir/Umur : : 71 Tahun

Jenis Kelamin : Laki-laki

Alamat : Banjar Pondok, Peguyangan

Kaja.

Pekerjaan : : Jero Mangku Pura Bale

Banjar Pondok

Nama

: I Wayan Sudiarta

Tanggal Lahir/Umur : Th. 1941

Jenis Kelamin : Laki-laki

Alamat

: Banjar Pondok, Peguyangan

Kaja.

Pekerjaan : Jero Mangku Kanginan, Pura

Luhur Catur Kanda Pat Sari Pangideran Dewata Nawa

Sanga 


\begin{tabular}{|c|c|}
\hline $\begin{array}{l}\text { Nama } \\
\text { Kesuma }\end{array}$ & : Putu Agung Gede Widia \\
\hline Tanggal Lahir/Umur & : 31 tahun \\
\hline Jenis Kelamin & : Laki-laki \\
\hline Alamat & : Banjar Pondok, Peguyangan \\
\hline $\begin{array}{l}\text { Kaja } \\
\text { Pekerjaan } \\
\text { (Wiraswasta) }\end{array}$ & : Kelian Adat Banjar Pondok \\
\hline $\begin{array}{l}\text { Nama } \\
\text { Tanggal Lahir/Umur } \\
\text { Jenis Kelamin } \\
\text { Alamat } \\
\text { Kaja } \\
\text { Pekerjaan }\end{array}$ & $\begin{array}{l}\text { : I Gede Sudiarcana, S.Sn. } \\
: \text { } 34 \text { Tahun } \\
\text { : Laki-laki } \\
\text { : Banjar Pondok, Peguyangan }\end{array}$ \\
\hline $\begin{array}{l}\text { Nama } \\
\text { Tanggal Lahir/Umur } \\
\text { Jenis Kelamin } \\
\text { Alamat } \\
\text { Kaja } \\
\text { Pekerjaan }\end{array}$ & $\begin{array}{l}\text { : Ni Wayan Yuniati } \\
\text { : } 13 \text { Juni } 1971 \\
\text { : Perempuan } \\
\text { : Banjar Pondok, Peguyangan }\end{array}$ \\
\hline $\begin{array}{l}\text { Nama } \\
\text { Tanggal Lahir/Umur } \\
\text { Jenis Kelamin } \\
\text { Alamat } \\
\text { Kaja } \\
\text { Pekerjaan } \\
\text { Wiraswasta }\end{array}$ & $\begin{array}{l}\text { : Pak Made Pujawan } \\
\text { : Th. } 1972 \\
\text { : Laki-laki } \\
\text { : Banjar Pondok, Peguyangan }\end{array}$ \\
\hline $\begin{array}{l}\text { Nama } \\
\text { Tanggal Lahir/Umur } \\
\text { Jenis Kelamin } \\
\text { Alamat } \\
\text { Kaja } \\
\text { Pekerjaan } \\
\text { Dedari }\end{array}$ & $\begin{array}{l}\text { : Ni Made Ariningsih } \\
: 22 \text { Tahun } \\
\text { : Perempuan } \\
: \text { Banjar Pondok, Peguyangan }\end{array}$ \\
\hline $\begin{array}{l}\text { Nama } \\
\text { Agustini }\end{array}$ & : Ni Luh Ketut Bintang \\
\hline $\begin{array}{l}\text { Tanggal Lahir/Umur } \\
\text { Jenis Kelamin } \\
\text { Alamat } \\
\text { Kaja }\end{array}$ & $\begin{array}{l}: 20 \text { Tahun } \\
\text { : Perempuan } \\
\text { : Banjar Pondok, Peguyangan }\end{array}$ \\
\hline Pekerjaan & : Mahasiswi Politeknik \\
\hline
\end{tabular}

